\title{
The Role of Mexico in the First Oil Shortage: 1918-1922, an International Perspective
}

\author{
Dr. M. del Mar Rubio* \\ DEE, Universitat Pompeu Fabra \\ Carrer Ramon Trias Fargas, 25-, Barcelona 08005 \\ mar.rubio@upf.edu
}

Tel: 935462674

Fax: 935421746

\section{Abstract}

In 1921 Mexico produced a quarter of world's petroleum, making the country the second largest producer in the world, but by 1930 it only accounted for 3 per cent of world's production. To date the discussion has mostly relied on events taking place in Mexico for explaining the decline of the industry. Very little attention has been placed to developments in petroleum industry elsewhere, except Venezuela. Practically no attention has been paid to the reasons for the rise of oil output in Mexico. This neglects the massive changes taking place in the petroleum industry worldwide during the Great War years and its aftermath, and overall ignores the shortage of oil that occurred in the world's markets between 1918-1921. These are crucial events in order to understand the early rise of the Mexican oil industry and set the basis for a better understanding of the subsequent sudden decline.

Keywords: world's petroleum supply, Mexico, First World War, energy shortage JEL codes: N700, N400, N560

\footnotetext{
* I am grateful to Marco Palacios and Pilar Gonzalbo for their support while at COLMEX, and to German Rojas for his support while at ITAM. Thanks also to the staff of the Biblioteca del Banco de México and Biblioteca Central de Petróleos Mexicanos for their assistance. The comments to earlier versions of this paper by the participants to seminars at Universidad Carlos III de Madrid, the ITAM and, the Universidad Autónoma Metropolitana en Aztcapotzalco were very helpful and encouraging. The financial support by the ESRC, LSE and the AGAUR is also acknowledged. The usual disclaimers apply.
} 


\section{The Role of Mexico in the First Oil Shortage: 1918-1922, an International Perspective}

\section{INTRODUCTION}

In 1921 Mexico produced a quarter of world's oil, making the country the second most important producer in the world, but by 1930 it only accounted for 3 per cent of world's production. In 1938 the petroleum industry was nationalised by the Mexican government and it took it over fifty years to regain the level of output of 1921. Two main lines of arguments have been used in order to explain the rapid decline of the Mexican oil industry during the 1920s. The first explanation argues that the decline was the result of the institutional change caused by the Mexican Revolution. The second hypothesis vindicates that Mexico simply run out of oil deposits that could be extracted at competitive costs given technology, prices and competing sources. Some authors have argued that both hypotheses are true. The problem is that the discussion has mostly relied on events taking place in Mexico, using sources and data exclusively relating to Mexico. Very little attention has been placed to developments in petroleum industry elsewhere, except Venezuela. Practically no attention has been paid to the reasons for the sudden rise of oil output in Mexico. This neglects the massive changes taking place in the petroleum industry worldwide during the Great War years and overall ignores the shortage of oil that occurred in the world markets between 1918-1921. These are crucial events in order to understand the rise of the Mexican oil industry and set the basis for a better understanding of the subsequent sudden decline.

Due to the Great War and the Soviet Revolution, Europe lost all its domestic supplies of oil and, become totally dependent on its Asian oil supplies (Dutch East Indies and British India) and overall, on the United States. Mexican oil was to play a major role at this time 
of shortage. This paper focuses on the rise of the Mexican oil industry by concentrating on the events taking place in the world's petroleum industry. Thanks to the data of the American Petroleum Institute, the U.S. Department of Commerce, and the Mexican Government it is possible to place Mexico in the changing context of the world oil markets of the early 1920s. In addition, it shed some extra light into the debate about the rapid fall of the industry.

The first section of this paper reviews the literature debate, revealing how little attention has been paid to the raise of the industry, and how much concentrated on events within Mexico has the debate remained. The second section steps out of Mexico in order to show the extensive changes taking place in the oil industry worldwide during the First World War and its aftermath, including the surge in demand and the awaken of nationalism world-wide regarding the exploitation of oil resources. The intense growth of demand for petroleum products was not followed by an equal growth in supply. The distortions introduced by the War, the Soviet Revolution, the cold winters of the end of the $1910 \mathrm{~s}$, plus the final War effort produced the first petroleum shortage of the $20^{\text {th }}$ century. Section three reveals the importance of Mexican oil at this time of shortage. Section four peeks at the sudden decline of the Mexican petroleum industry departing from the depiction of the rise of the industry provided in earlier sections. The conclusions summarise the main findings of this paper.

\section{THE RISE AND FALL OF THE EARLY MEXICAN OIL INDUSTRY: A REVIEW}


The development of the oil industry in the South of the United States and the similarity of its coastal area to that of northern Mexico attracted world-wide attention in the first two decades of the $20^{\text {th }}$ century. A long dictatorship, Porfirio Díaz (1876-1911), brought political stability and legal facilities that encouraged foreign investors to explore the countries' oil ${ }^{1}$. Mexico started commercial oil production in 1901, although it took almost a decade to produce meaningful amounts. In the following decades hundreds of oil companies were organized to exploit the Mexican subsoil. Between 1911 and 1921, the foreign enclaves, especially the oil industry, stood out as islands of prosperity in the sea of destitution caused by the Mexican Revolution ${ }^{2}$. In the midst of coups, revolutions, counter-revolutions and a general state of civil war, the oil companies managed to make of Mexico the world's main oil exporter and second world's producer.

At its peak, Mexico produced a quarter of world's oil, but ten years later in 1931, it only accounted for 3 per cent of world production. As it can be observed in Figure 1, it took over fifty years to regain the level of output of 1921. Two main lines of arguments have been used in order to explain the rapid decline of the Mexican oil industry in the 1920s. The first explanation argues that the decline was the result of the institutional change caused by the Mexican Revolution. The second hypothesis vindicates that Mexico's oil fields simply become exhausted. Some authors have argued that a fatal combination of both gives reason for the rapid decline of the Mexican oil industry.

\footnotetext{
${ }^{1}$ The following works provide good insight into the economic history of the early part of the twentieth century: Cárdenas (1992-1994); Colegio de México (1960); Colegio de México (1965); Haber (1989); Reynolds (1970).

2 Knight (1992), p.295. See also Thorp (1998), p.68 and Reynolds (1970) who initially demonstrated this.
} 


\section{Figure 1}

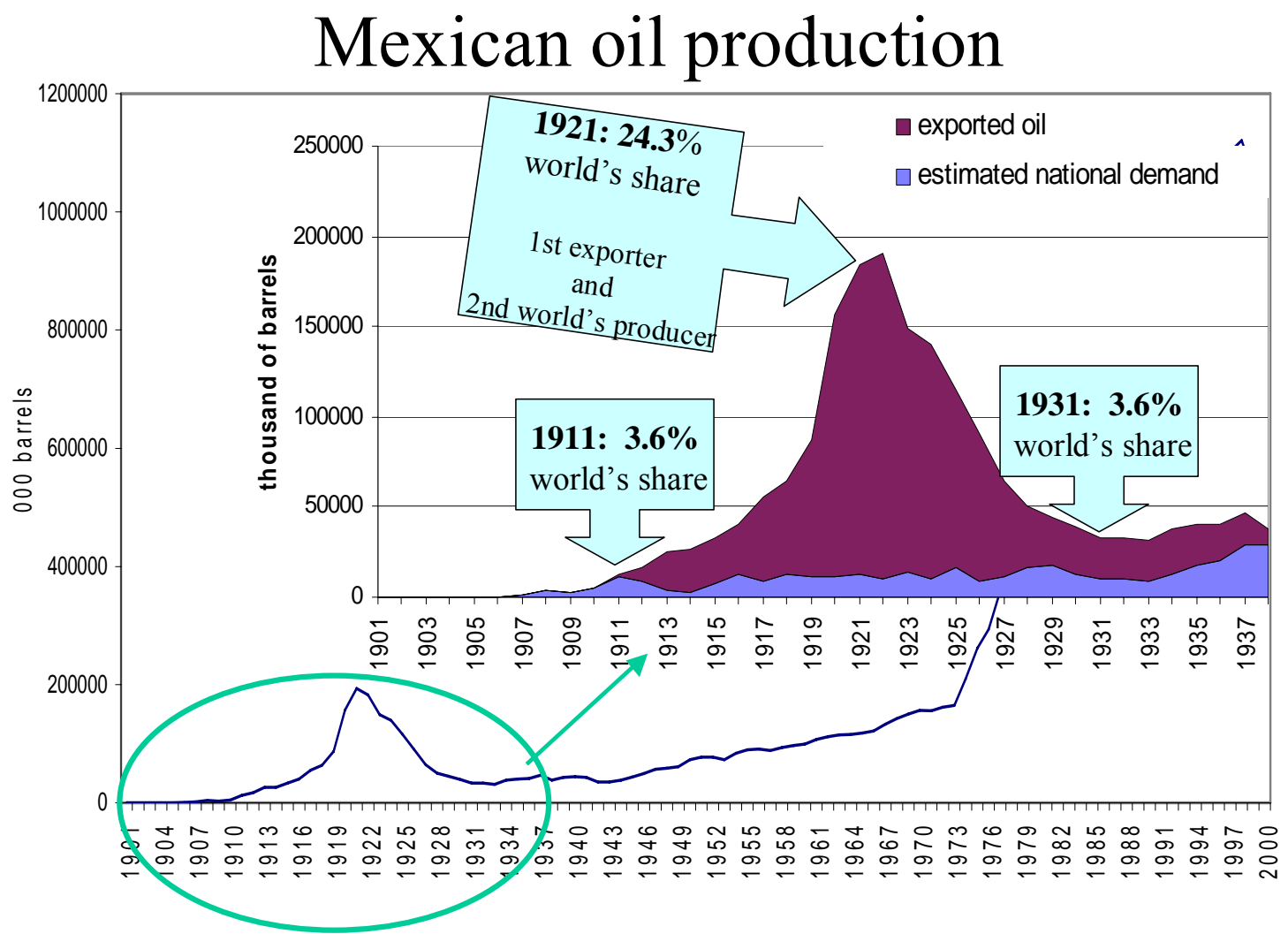

Sources: elaborated using oil production data 1901-1992: México. Instituto Nacional de Estadística Geografía e Informática (INEGI) (1994), cuadro 11.1, p.559. Estimated national demand for oil obtained by subtracting exports volume from total production. Exports of oil sources: 19111936:México (1937 December); 1937: Haber et al. (no published);1938-1939: PEMEX (1952) p. 47. World's production from American Petroleum Institute (1937).

Those who favoured the institutional explanation focused on the increasingly tense relationships between the post-revolutionary Mexican governments and the foreign companies operating in the country ${ }^{3}$. The issue came down to two things: the stability of agreements and the question of sovereignty and ownership ${ }^{4}$. From 1884 to the enactment of the Mexican Constitution of 1917, concessions for the exploitation of mineral deposits

\footnotetext{
${ }^{3}$ The first chapters of the following books, provide a good review of the initial stages of the Mexican oil industry: Grayson (1980 ); López Portillo (1975); Menéndez (1958); Owen (1975); PEMEX (1988), Vol. 1, and Chapter 8 in Rippy (1972). For Mexican governments relations with the companies see the first chapter of Bermudez (1963) and also Baldridge (1987).

${ }^{4}$ Yerguin (1991), p.232
} 
were freely granted to foreign individuals and companies, and there were no restrictions on natives selling oil lands to foreigners. Article 27 of the 1917 Constitution made again all subsoil wealth the property of the nation, returning to the several centuries old legislation of the Spanish mining code. Although, in principle, the new law could not have retroactive effects, various other actions by successive Mexican governments regulations, tax hikes, the creation of Federal reserves - fuelled continuing conflicts with oil companies and led to diplomatic protests by the Governments of the United States, France and Great Britain over the next decade ${ }^{5}$. Additionally to the threat of arbitrary deprivation of vested rights, the companies also had difficulties with the workers in the oilfields, who got increasingly organized after the Revolution ${ }^{6}$. From this description it derives that the increasing nationalist tendencies of the successive post-revolutionary Mexican governments paralysed exploration and reduced production by foreign companies, leading to the early decline of the Mexican oil industry.

Other authors reject the importance of the institutional factors in the decay of the Mexican oil industry. For instance, Thorp (1989) argued that the potential threat posed by the 1917 Constitution was not taken very seriously in the 1920s. Haber et al. (2003) also argued that the calls for intervention and punitive sanctions against Mexico by the American oil companies, and the corresponding protests by the U.S. State Department in their behalf, should not be taken as evidence that the oil companies were genuinely threatened, should instead understood a signal by the U.S. government that it would enforce American property rights. The US Congress was not the oil companies' only

\footnotetext{
${ }^{5}$ Federal reserves implied the retention of land for further exploration and potential exploitation by the state. For a discussion of Federal Reserves see López Portillo (1938). For a synthetic historical overview of events see Haber et al. (2003).

${ }^{6}$ Novelo (1991); Ramirez Heredia (1979); Adleson (1992).
} 
recourse; the companies, it has been argued, could also withhold output and deny the Mexican government crucial tax revenues. Figure 2 shows the importance of petroleum taxes for the Mexican government, at its maximum they accounted for almost 20 per cent of the fiscal income of the government.

\section{Figure 2}

Petroleum taxes vs othertaxes (Mexico 1901-1938)

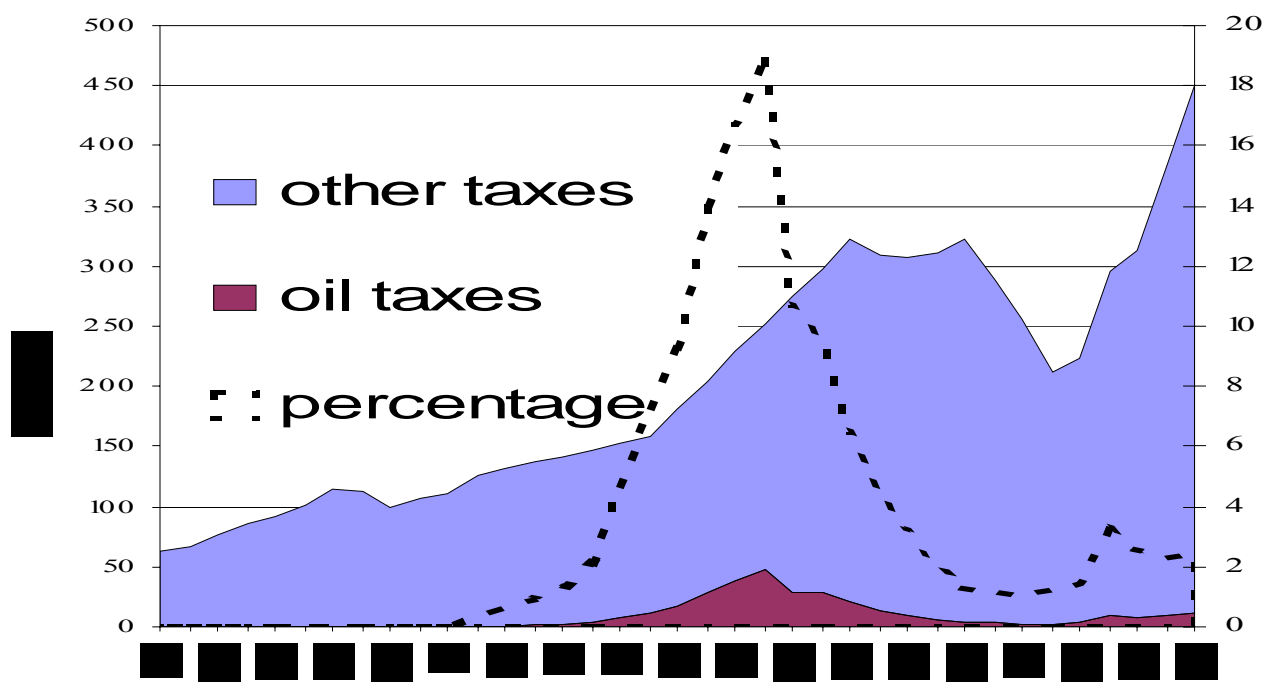

Sources and notes: Left axis in million of current pesos, percentage of oil taxes on total fiscal income on the right axis. Own elaboration from data on oil taxes from: 1912-1920: México (1925);19201933: México. Secretaría de Hacienda y Crédito Público. Departamento de Impuestos Especiales. Sección de Petróleo (1936a); 1934-1936: Ibid. plus royalty payments from México. Secretaría de Patrimonio Nacional (1963); 1937: México. Secretaría de Hacienda y Crédito Público. Dirección General Técnica de Ingresos. Oficina de Investigaciones Económicas (1938), p. 387. The data on total fiscal income from: 1901-1911 and 1925 onwards: México. Instituto Nacional de Estadística Geografía e Informática (INEGI) (1994);1912-1924: It is possible to infer government income for 1912 and 1918 from thedata provided by Wilkie (1967), Table I.II, p.28. The gaps were then filled linearly.

On the side of the companies, it seems, increases in taxes had only a minor impact on corporate rates of return. In fact, it has been also claimed by Haber et al. (2003), the companies continued to explore and invest well after output began to fall. They simply could not find sources of petroleum that could be extracted at a reasonable price using existing technology. Mexico’s petroleum industry went into decline because Mexico ran out of oil. 
Actually, Mexican scholars were the first to advance the geological explanation -the exhaustion of Mexican oil fields - in the 1930s. Most Mexicans did not view the petroleum industry developed by foreigners as an unmitigated blessing. As reported in Brown (1993) the Mexicans accused the wealthy companies of financing reactionary political movements, dividing and repressing the workers, extracting the nation's nonrenewable resources, and subordinating domestic needs to the international interest, making huge profits in the process. Following this line, Mexicans had their own justification for the decline of the oil industry. From the Mexican point of view, as reported in Manterola (1937), the companies exhausted oil fields in order to cope with demand. The so-called limitless capacity of Mexican oil fields turned into fears of exhaustion in the early 1920s. More capital would have been invested in further development of the Mexican industry, if Mexican oil fields had not been over-exploited beforehand $^{7}$. The general agreement among Mexican scholars was that oil exploitation could not be done in a sensible manner when there were several companies involved ${ }^{8}$. According to this view, fields were being totally exhausted under private exploitation. Oil was such an important element that its exploitation should be beyond individual interest. Oil should not be extracted for profit but for the salvation of a society. In addition, the companies were accused of hiding profits (see Silva Herzog (1938)). The companies were said to be distorting information about their profit margins in order to evade taxes. The companies were not only exhausting Mexican oil, but also going away without paying any compensation.

\footnotetext{
${ }^{7}$ At least that is the Mexican view expressed by several authors in the monthly journal of the National Union of Mexican Economists - Revista de Economía- quoted below. It is also the view of Sangines Villavalva (1938 Marzo).

8 The following sentences mostly come from: López Portillo (1938). Identical views are expressed by Sangines Villavalva (1938 Marzo)
} 
A combination of the institutional and the geological explanations has also been put forward. Both problems hit almost simultaneously: salt water started to intrude into big Mexican producing wells as early as 1918 , only few months after the new Constitution was passed. According to Yerguin (1991):

'The salt water was very bad news- it meant the beginning of a decline in oil output. The problem could have been conquered with more capital, better technology and new exploration. But in the midst of the revolutionary turmoil, the foreign companies were loath to step up their investment.'

While the companies and the government were settling their disputes in Mexico, Venezuela captured the attention of the oil companies. A huge per-well production in the Maracaibo baisn after 1922; low transport costs $;{ }^{9}$ low political risk factors (an allpowerful dictator and a docile labour force); and the best petroleum law in the world combined to give Venezuela an important international cost advantage. As Brown (1985), put it 'the oilmen shifted their interest from Mexico to Venezuela because the loss of Mexican oil's competitiveness, a loss reinforced but not caused by revolutionary nationalism.' From this perspective, geological and institutional factors combined to the detriment of the Mexican oil industry.

The different explanations are sustained on different kinds of evidence. The institutional explanation was primarily supported on the diplomatic correspondence between the companies, their respective governments and the Mexican authorities. It also made use of the analysis of the legal changes made by the latter. The exhaustion story, supported by the Mexican scholars, was encouraged by the nationalistic feelings assisted by the immediate evidence of the day: sanding-up of wells and sinking production. The

\footnotetext{
${ }^{9}$ Most of the fields were situated in the Eastern shore of Maracaibo Lake. Lake and ocean tankers were used. They were able to transport huge amounts of crude at a very low cost.
} 
combined explanation came into light when companies' records became available. It was then possible to add some patchy quantitative evidence to the debate, emphasizing some of the economic determinants. Nevertheless, as Haber et al. (2003) argued, these studies 'do no bring to bear much in the way of systemically retrieved and analysed data'. Their retrieval and analysis of additional data on average taxes, corporate profits, capital stocks and flows supports the geological explanation.

Regardless the nature of the evidence used, all explanations have a common feature: the narrow focus on Mexico. Very little attention has been placed to developments in petroleum industry elsewhere, except Venezuela. Practically no attention has been paid to the reasons for the sudden rise of oil output in Mexico. The rise is almost taken as an inevitable fate. This neglects the massive changes taking place in the petroleum industry worldwide during the Great War and the early twenties. Overall it ignores the shortage of oil that occurred in the world's markets between 1918-1921. These are crucial events in order to understand the rise of the Mexican oil industry and set the basis for a better understanding of the subsequent sudden decline.

\section{THE EARLY PETROLEUM INDUSTRY AND THE OIL SHORTAGE OF 1918-1921}

The First World War was responsible for the rapid maturity of the petroleum industry. Just prior to the war, both the U.S. and Great Britain began the conversion of their naval fleets from coal to oil burners. Not only did petroleum propel the newest and fastest war vessels but it also provided fuel for such military innovations as the submarine, the tank and the airplane. As DeNovo (1956) remind us, oil-fed trucks and autos played a military role at war, while petroleum was even a basic constituent of TNT. 
The stimulus imparted to industrial and transport technology during the war enormously increased the postwar demand for petroleum products. The merchant fleet and the railways (specially those of the Americas) started the switch to fuel oil engines.

According to the data of the American Petroleum Institute (1937) and the Lloyd's Register of Shipping (s.d.) showed in Figure 3, in 1914 only 3 per cent of the tonnage shipped in the world was on an oil burning ship. The share grew to 15 per cent in 1920 , 31 per cent in 1924 and, by 1934 almost half of the worlds tonnage was on board of an oil burning ship. According to the same sources, in the case of the U.S. flag fleet, more than half of the cargo was shipped using oil as locomotive fuel; To be precise, 62 per cent by 1924 and 71 per cent in 1934, in contrast to the 15 per cent in 1914.

\section{Figure 3}

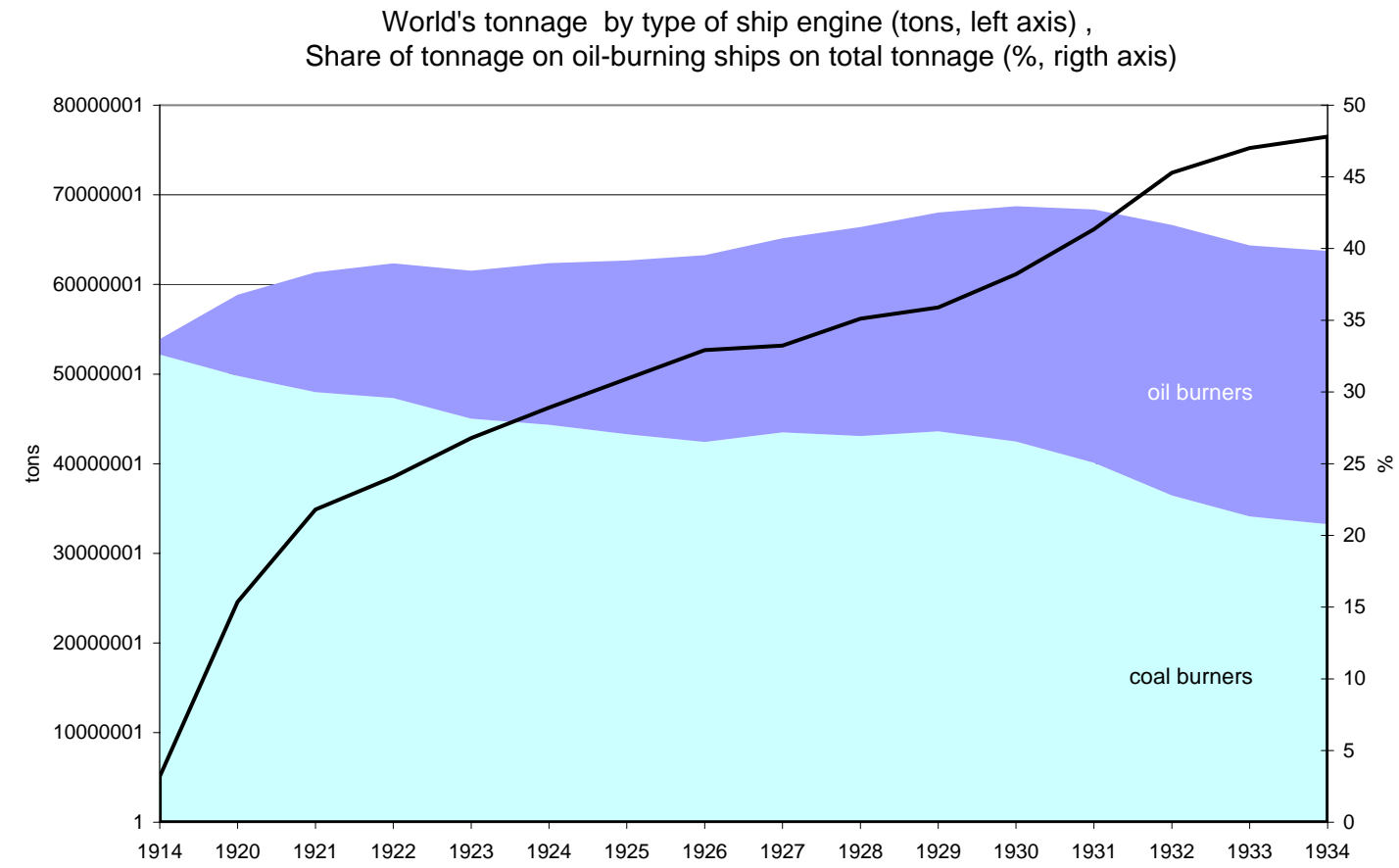

Sources and notes: Elaborated from data American Petroleum Institute (1937), p.30 for tonnage in oil burning ships. World's total from the Lloyd's Register of Shipping ). Tonnage of Oil -burning ships, exclusive of Army, Navy and other government oil burners. 
The increasing number of motor vehicles (cars, trucks and busses) also demanded more oil. According to the statistics of the American Petroleum Institute (1937) and the estimates by Yerguin (1991), the number of registered vehicles in the U.S. rose from 1.8 million in 1914, to 10.4 million in 1921 . The 26.5 million registered vehicles of 1929 represented 78 per cent of the estimated motorcars in the world.

Also the industry required more oil. The use of fuel oil and diesel engines as prime movers and as electricity generators in places with either little hydraulic resources or coal, together with the necessary lubricants for the machinery, also increased the demand for petroleum products in the 1920s. The U.S. Department of Commerce (by J.R. Bradley) (1931) estimated that by the end of the 1920s, in round numbers, and excluding oil used by oil companies, about 37 per cent of all petroleum was used to produce gasoline, 5 per cent for lubricants, while kerosene, the major market in the early days of the industry, only used 8 per cent of all petroleum produced. Practically all the remainder half was used as gas or fuel oil. This fuel oil was principally used for bunkering ships and as locomotive fuel, for which coal, supplied largely by Great Britain, was formerly used. Nevertheless, the contribution of oil to the world energy supply at this time must not be exaggerated. In 1925, solid fuels supplied 82,9 per cent of the energy consumed, liquid fuels, 13.2 per cent, natural gas 3.2 per cent and hydroelectric power 0.7 per cent (See Darmstadter and al. (1971)).

Between the other results of the War a spirit of nationalism was awakened in all countries, which involved the ideas of self-determination, self-preservation and national security. The latter idea immediately suggested the importance of conserving the natural resources and raw materials of any given country. These considerations led to the 
adoption of governmental programs of exclusion or discrimination against foreigners, together with the development of their own natural resources by their own citizens. In form, such protection was either legislative, as, for example, the enactment of restrictive laws; contractual, as in the case of an agreement between the Government and its citizens for the working of large areas to the exclusion of aliens; or administrative, as where the granting of concessions was left to the discretion of some executive officer who favored the nationals of his own country. In this context, Mexico's raising nationalism was not unique, but rather the norm among the oil producing countries in the early 1920s. The surge in demand was not coupled with an equally intense growth in the supply of oil. For the first years of the War demand was well ahead of oil supply. Before the War, the U.S. produced about 60 per cent of the petroleum produced in the world ${ }^{10}$. The second larger producer was Russia, with 20 per cent of the world's production, or in other words, about half of the production outside the U.S. was Russian production. In fact, from 1898 to 1901 Russia led the world in petroleum production. The remaining production was more or less distributed in shares of 2 to 5 per cent of worlds production between Mexico, the Dutch East Indies, British India, Rumania and what it will become Poland after the war. Figure 4 shows the world's oil production between 1900 and 1936 by main producer countries.

\footnotetext{
${ }^{10}$ Unless otherwise stated, all data on production of petroleum used in the paper comes from American Petroleum Institute (1937) pp.56-57.
} 


\section{Figure 4}

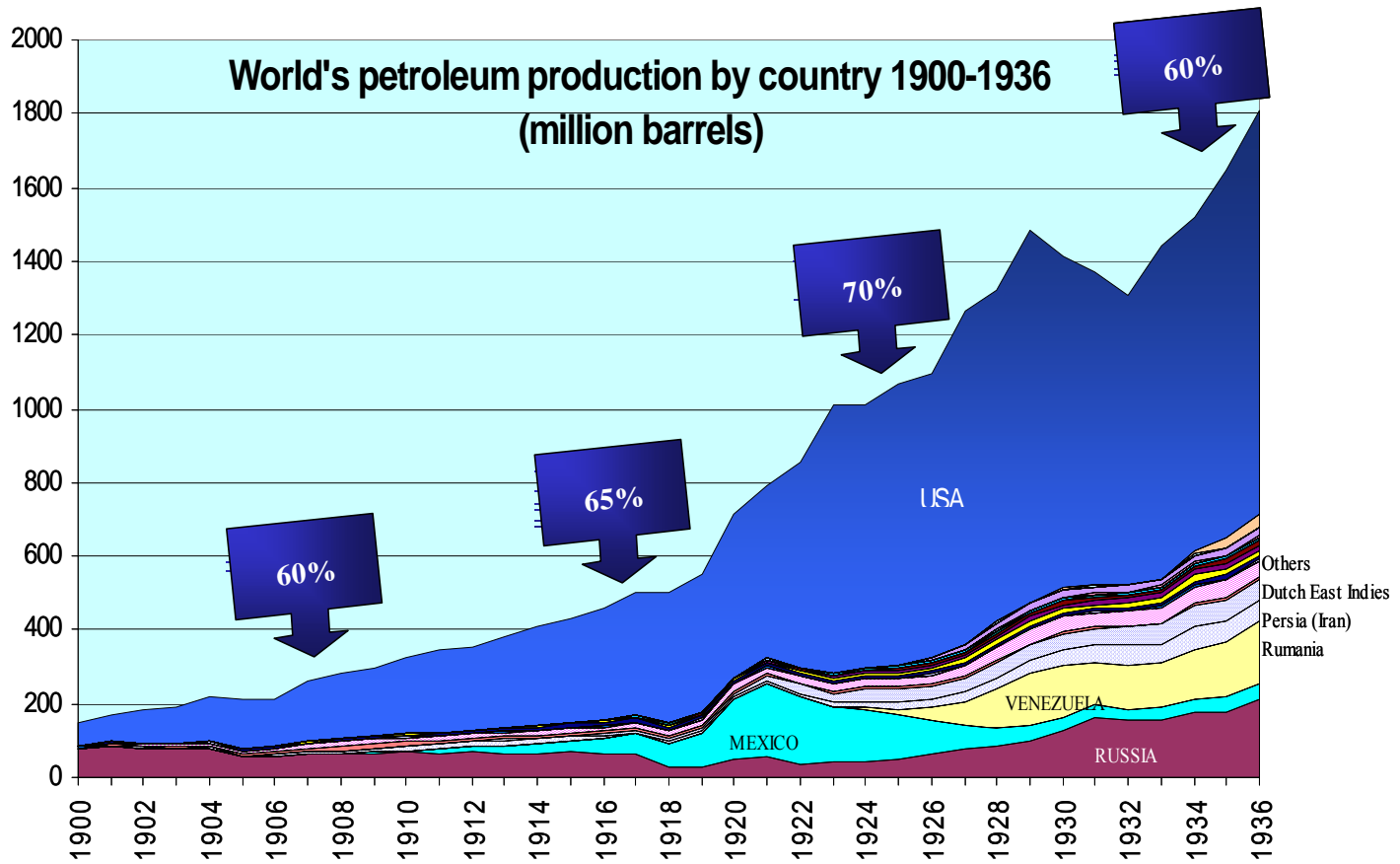

Sources and notes: shares correspond to the USA. Data from American Petroleum Institute (1937)

The collapse of the Russian production started the shortage of oil 1918-1921. As mentioned by Yerguin (1991) during the War oil become the "blood of victory". Unlike Rumania and Poland, and despite the shortage of manpower during the War years, Russia managed to keep its petroleum production running and remain as the second larger world's producer. What hampered Russia's production was the Bolshevik revolution. Both Baku and Grozny (the main oil producing regions) changed hands twice between 1918 and 1920, and according to U.S. Department of Commerce (by W.A. Ottis) (1924), during the fighting much of the oil property was destroyed and a large number of the remaining operatives killed. As a consequence, Russian production halved, and it did not recover its pre-revolution levels until 1926 as it can be seen in Figure 5, which shows the supply of oil outside the United States for the period 1900-1936. 


\section{Figure 5}

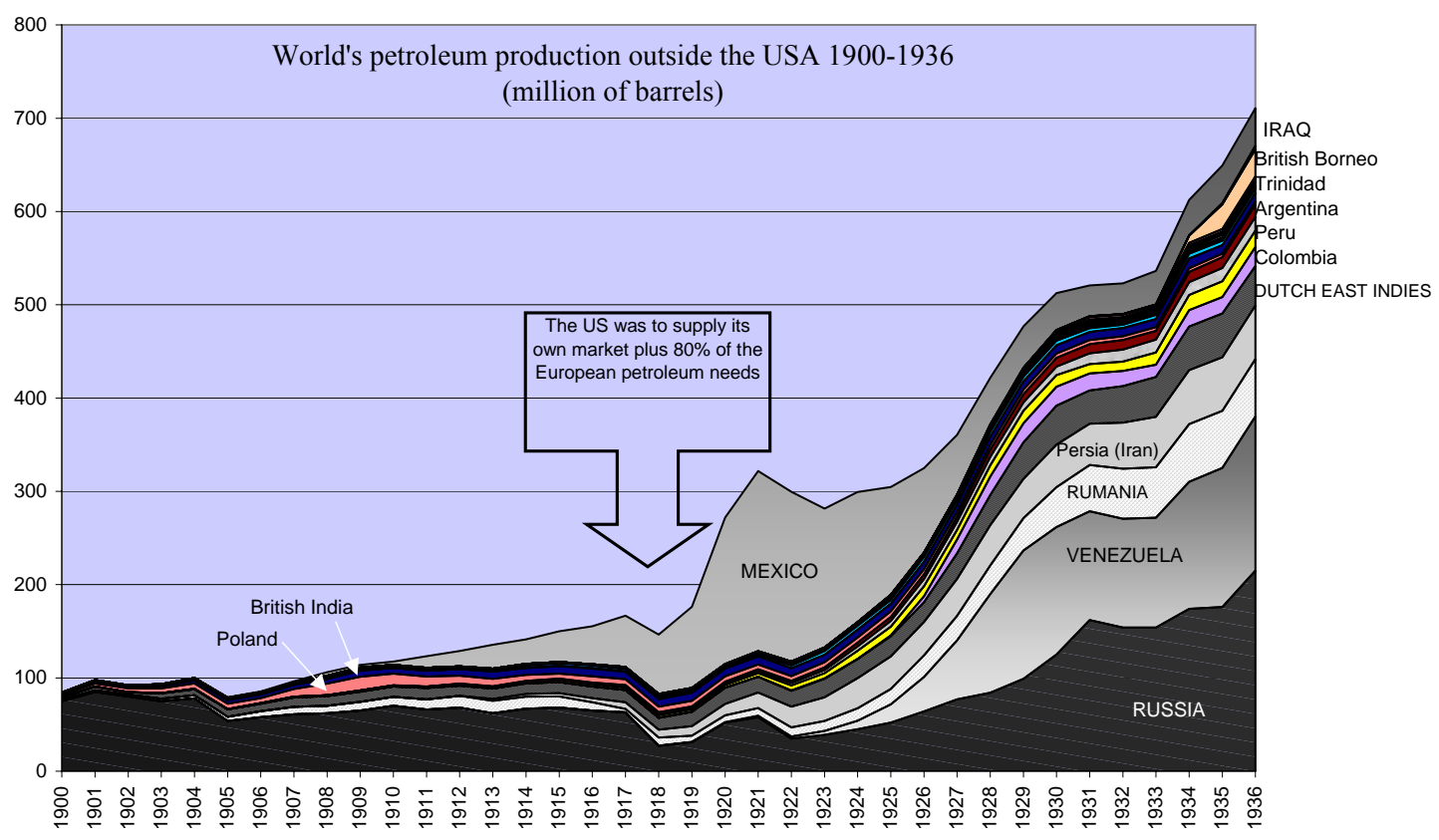

Source : American Petroleum Institute (1937).

Lost all its domestic oil supplies, the Old Continent was dependent on its Asian oil supplies (Dutch East Indies, Persia and the British India) all of which produced then insufficient amounts to satisfy the European needs and were too remote. Overall the European markets become utterly dependent on the U.S.

The collapse of the main European sources of petroleum coupled with a concatenation of cold winters $\left(1918,1919\right.$ and 1920 were some of the coldest of the $20^{\text {th }}$ centuries at both sides of the Atlantic), the final War effort and, the increasing difficulties to obtain new petroleum concessions given the awaken nationalism over the exploitation of natural resources.

In fact, Mexico was neither the first nor the most radical country adopting nationalistic positions in this respect as demonstrated by a report of the U.S. Federal Trade Commission (1923) on petroleum ownership. In Russia, all movable or immovable 
property belonging to the petroleum industry, including the Caspian commercial fleet, was declared property of the State by decree in June 1918. In addition, trading in oil was made a State monopoly, production and distribution being placed under the general management of the chief petroleum committee of the fuel department of the supreme council of national economy. Agitation for nationalization of the petroleum industry also heated up in Rumania, the second larger producer in Europe before the War. In November 1918, large land areas were expropriated from both native and foreign owners and resold to peasants, the Government reserving the subsoil rights. The uncertainty regarding further steeps towards nationalization of the Rumanian oil industry will remain for most of the first half of the 1920s.

Dutch and British also procured mutually exclusive rights in their overseas dominions. In practice, the Dutch-Shell group had secured a quasi-monopoly in the East Indies, while the British Government adopted a policy of complete exclusion of aliens in respect to the oil fields of British India, particularly those of Burma. Anglo-Persian also held almost exclusive rights in Persia.

It was not any easier to obtain new oil rights in Latin America. Argentina was the first Latin American country to establish a national oil company, YPF (1907) and one of the first to pass strict legislative measures in order to limit the activities of private oil companies (see Philip (1982)). From 1919 and for the first years of the 1920s, both Colombia and Ecuador tried (but mostly failed) to enforce petroleum laws inspired on the Mexican legislation. Despite several modifications to the original laws, the foreign companies argued that the legislations of both countries were far from satisfactory for their interest. According to Wilkins (1974), in Peru and Bolivia the problems were no so 
much legislative over property and concessions, as fiscal. Long running conflicts about tax evasion and fraud affected the development of oil production in both countries. Therefore, it is clear that the very few countries that offered open door policies, such as Venezuela, Canada, Poland, Egypt or South Africa, were exceptional among the oil producing countries of the early 1920 s.

The supply problems led to the creation of the Inter-Allied Petroleum Conference. It was established in February 1918 to pool, coordinate, and control all oil supplies and tanker shipping and along with the introduction of convoys as an antidote to German U-boats-it attempted to solve the Allies' oil supply problems for the rest of the war. Mexican oil was to play a major role at this time of shortage.

\section{THE ROLE OF MEXICO IN THE FIRST OIL SHORTAGE}

The Inter-Allied Petroleum Conference was also crated in response to domestic American energy problems. Following Yerguin (1991) estimates, the U.S. was serving its own demanding market plus 80 per cent of the European requirements for oil. By 1918 the surging demand for American oil began to hit the limit of available supplies. The gap was being closed only by using up inventories and by importing more oil from Mexico. Even when imports from Mexico trebled between 1918 and 1921, U.S. petroleum inventories keep falling month after month for most of those three years as shown in Figure 6. Average crude oil prices at well, which had doubled in the U.S. from the beginning of the War, will jump another 50 per cent in the couple of years after the armistice (see Figure 8 below). 


\section{Figure 6}

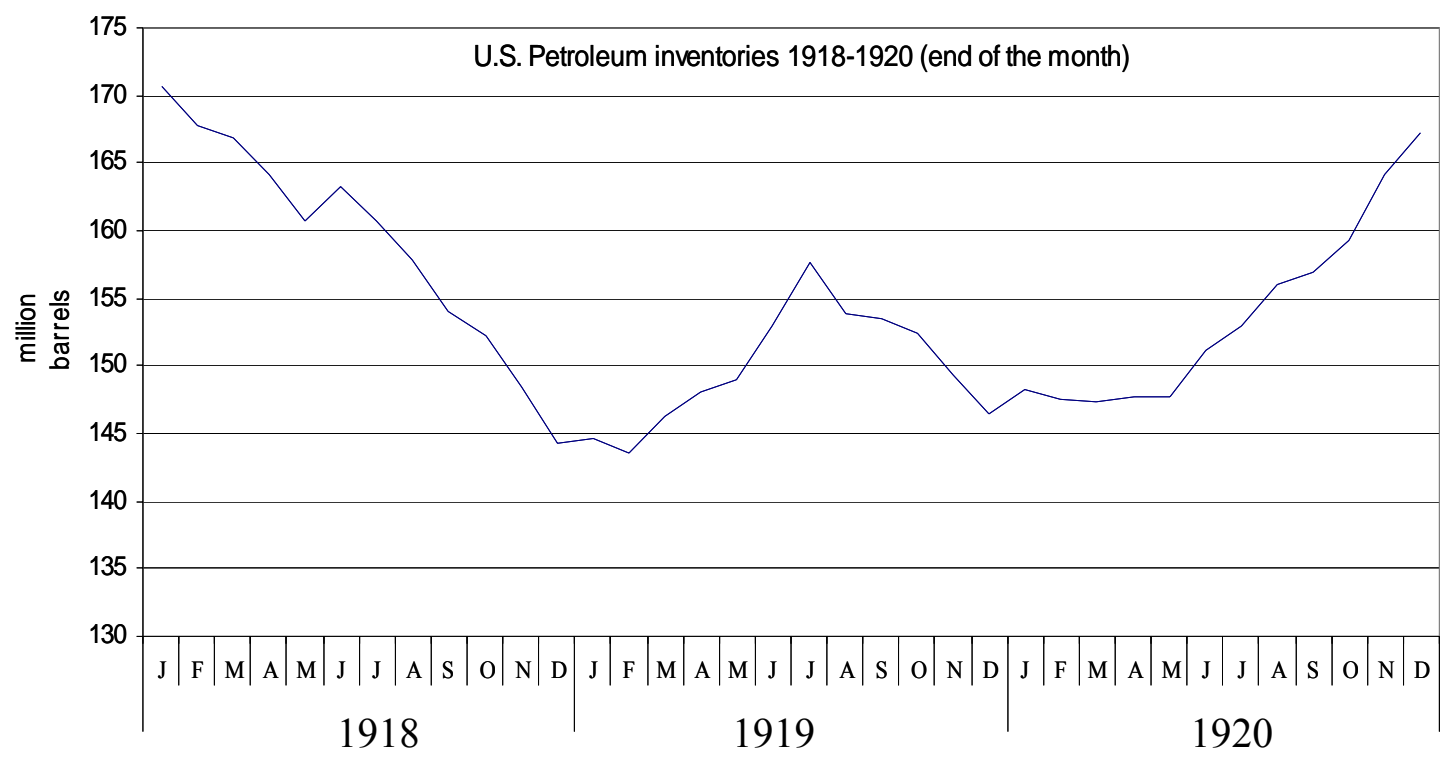

Source: U.S. inventories of oil from NBER (2003)

The importance of imports from Mexico in those years should not be underestimated. The shrinkage of the Russian production implied that Mexico was to produce more than half the oil outside the U.S. from 1919 to 1923 . In addition, Mexico was the only place from which the U.S. imported crude oil until 1921, and by 1925 it still made 89 per cent of all U.S. imports of crude oil. It could be argued, however, that imports never accounted for a big share of the total U.S. oil supply; at its peak imports accounted for a fifth of the total U.S. supply. Yet, Mexico contributed to the oil supply of the U.S. as much as any of the oil producing states of the Union. In fact, the Mexican state of Veracruz was the principal individual "state" contributing to the U.S. total oil supply. As it can be appreciated in Figure7, by 1921, Mexico, in particular the state of Veracruz produced for the U.S. market more than either of the bigger domestic oil producers of the time: California, Oklahoma or Texas. 


\section{Figure 7}

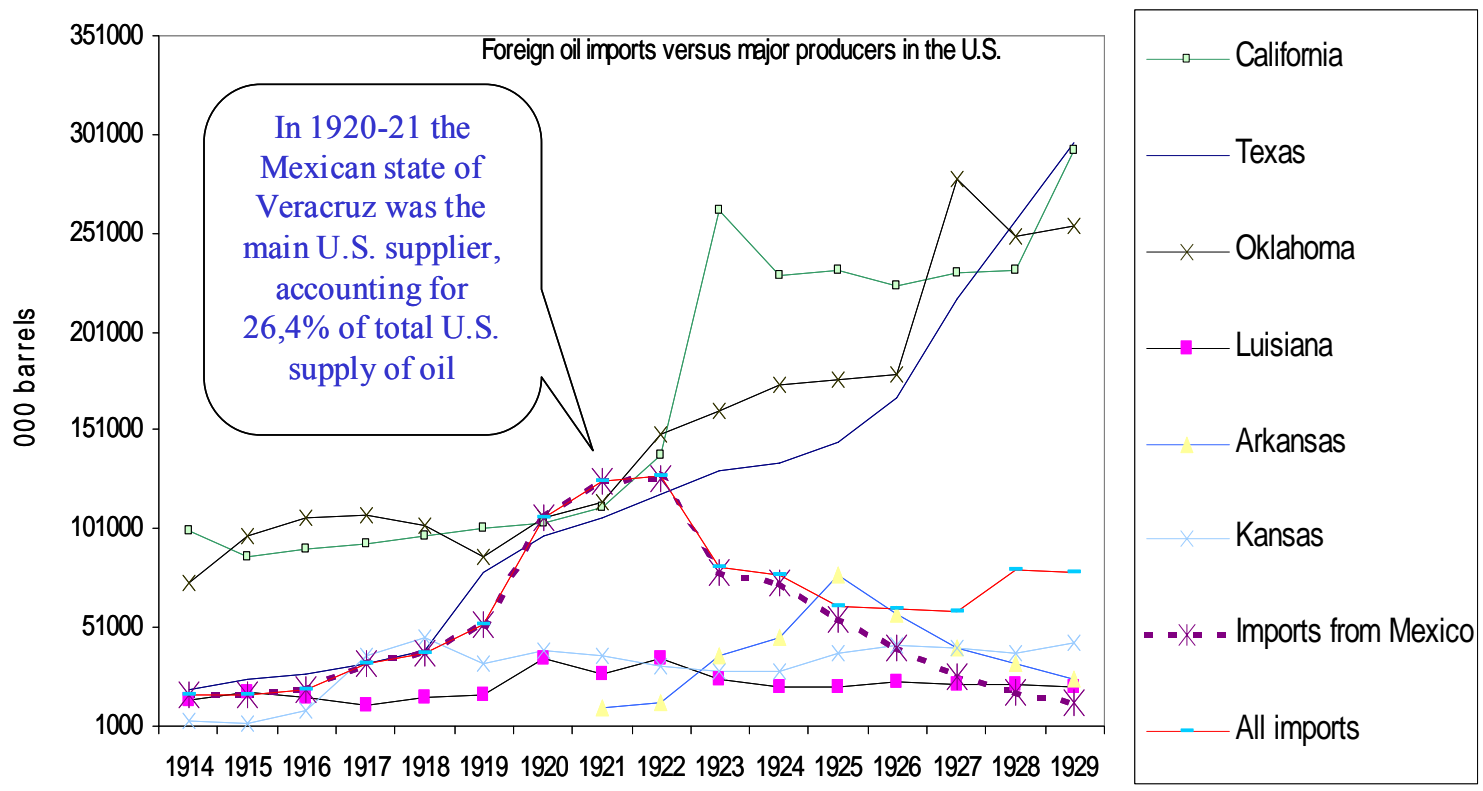

Source: American Petroleum Institute (1937) pp.62-63 for U.S. production by state and p. 208 for imports of crude oil into the U.S. by country of origin.

Moreover, Mexican fields were better located than the main U.S. domestic fields to supply the cities of the Atlantic coast where ships were awaiting filled with materials for Europe. Domestically U.S. produced petroleum had a long way to travel to the East coast. From California the options were either to ship the oil via the Panama channel or by rail since the West coast was not connected by pipe-lines with the rest of the country, while Oklahoma had no access to sea transport and had to make use of pipelines and rail and most of Texas oil made it to the Gulf Coast first and then be shipped to the Atlantic refineries. Mexican oil fields, per contrast, were very close to the Gulf and crude could be immediately shipped. 


\section{Figure 8}

Average price, location of oil production and price gradient in the US by 1920s

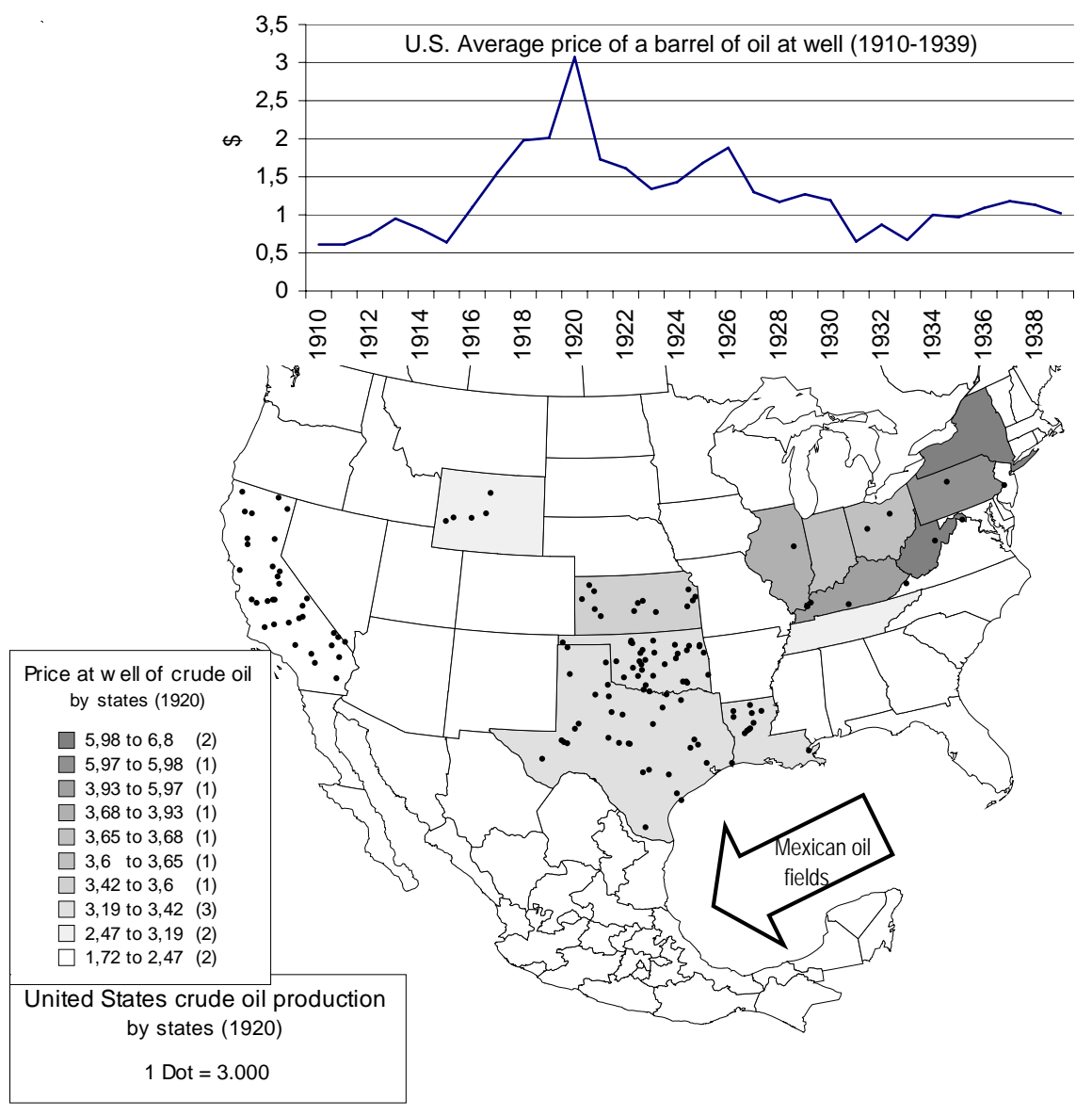

Source: American Petroleum Institute (1937)

Indeed, the shortage of oil was worse felt in the Atlantic Coast. While it is true the average price oil at wellhead paid in the U.S. rose from $\$ 0,64$ in 1914 , to $\$ 3.07$ in 1920 , it is also true that the price rises where much bigger in the East than in the West Coast: in 1920 a barrel in California cost $\$ 1.72$, while in the other side of the country, in the state of New York, the price of a barrel of oil was $\$ 5.98$. The location of oil production and the price gradient in the U.S. of the year 1920 are shown in Figure 8.

Distance from the oil producing regions to the U.S. consumers gave some cost advantage to foreign oils. The U.S. officials acknowledged the importance of foreign oil in 
supplying the American East coast in the reports on petroleum on U.S. Department of Commerce (various years). It was more expensive to deliver domestically produced oil from California or the Mid Continent to the East Coast than Mexican oil. According to the calculations of the U.S. Tariff Commission (1932) the costs of production and delivery to refineries on the Atlantic seaboard of domestic oil exceeded those of Mexican oil still by the end of the twenties. The costs of putting domestic oil on the Atlantic seaboard were calculated at $\$ 2,17$ per barrel while those of Mexican oil were estimated at $\$ 1.44$ in 1927 . That is including the costs of production, transportation (pipeline plus ocean tanker) and taxes. Given this framework it is very unlikely that the companies could lodge a credible threat to shut down production in Mexico in order to put pressure on the Mexican government by withdrawing the vital oil taxes. If anything, the dependency was mutual in those years.

From this depiction it is clear that Mexican crude oil played the crucial role of supplying the U.S. at this time of shortage, so that at the same time, Europe could be also supplied. By focusing in events outside of Mexico rather than within Mexico it is easier to understand than the rise of the Mexican oil industry had a lot more to do with the events in the international petroleum markets than with mere natural resources lottery as it has been usually portrayed. Mexican oil fields were required to produce at their maximum capacity in the few year the world's market were in most need of oil due to the combination of events described in the previous sections. Consequently Mexico raised to be the second largest petroleum producer in the world after the United States and the largest exporter of petroleum. A position that was short-lived. Whether the fall of the 
industry was rooted in this peculiar mode of rising is the issue of the last section of the paper.

\section{THE END OF THE SHORTAGE AND THE END OF THE MEXICAN OIL SURGE}

Surely, events within Mexico had an impact on the decline of the industry. Nevertheless, it is worth wondering whether parallel to these internal developments, events outside the Mexican (and Venezuelan) territory also had importance in the decline. Given the nature of the rise, it is just natural to peek into the declining side of the story in order to find out whether the end of the shortage and the changes in the international markets can shed some extra light into the debate about the rapid fall of the early Mexican industry. Total petroleum output peaked in 1921, and exports of crude and derivatives peaked a year later. The traditional accounts of what followed normally describe the sudden plunge of the Mexican oil industry. A closer look at the Mexican data reveals a different timing. Only two things peaked in the Mexican oil industry in 1921: the flow of investment into the industry (as it will be revealed in a moment), and the output and exports of light oil. Exports of fuel oil and natural gasoline peaked in 1922. Heavy oil output and exports reached their maximum by 1924; Exports of refined gasoline and crude kerosene in 1925; Exports of asphalt in 1927, and those of gas-oil and lubricants in 1929. Finally, by 1930 more refined kerosene was exported from Mexico than ever before ${ }^{11}$.

\footnotetext{
${ }^{11}$ Mexican exports by type of products México. Secretaría de Hacienda y Crédito Público. Departamento de Impuestos Especiales. Sección de Petróleo (1936a) and México. Secretaría de Hacienda y Crédito Público. Departamento de Impuestos Especiales. Sección de Petróleo (1936b). Mexican production by type of oil from México. Secretaría de Hacienda y Crédito Público. Dirección General Técnica de Ingresos. Oficina de Investigaciones Económicas (1938), pp.117-118.
} 
In 1924 Mexico still produced 46 per cent of all the oil produced outside the U.S. Despite the decline in output through the 1920s, Mexico remained as the main oil producer outside the U.S. until the end of the decade when Venezuela first (1928) and the Soviet Union later (1931) took that position. Mexico kept on supplying some of the major oil markets outside the U.S. such as the United Kingdom, Germany or Cuba as it can be seen in Figure 9. Therefore Mexico did not suddenly turn into an inconsequential oil producer by but remain as main oil exporter until well into the 1930 as it can be observed in

Figures 4 and 5 above.

\section{Figure 9}

Mexican exports of crude oil and derivatives

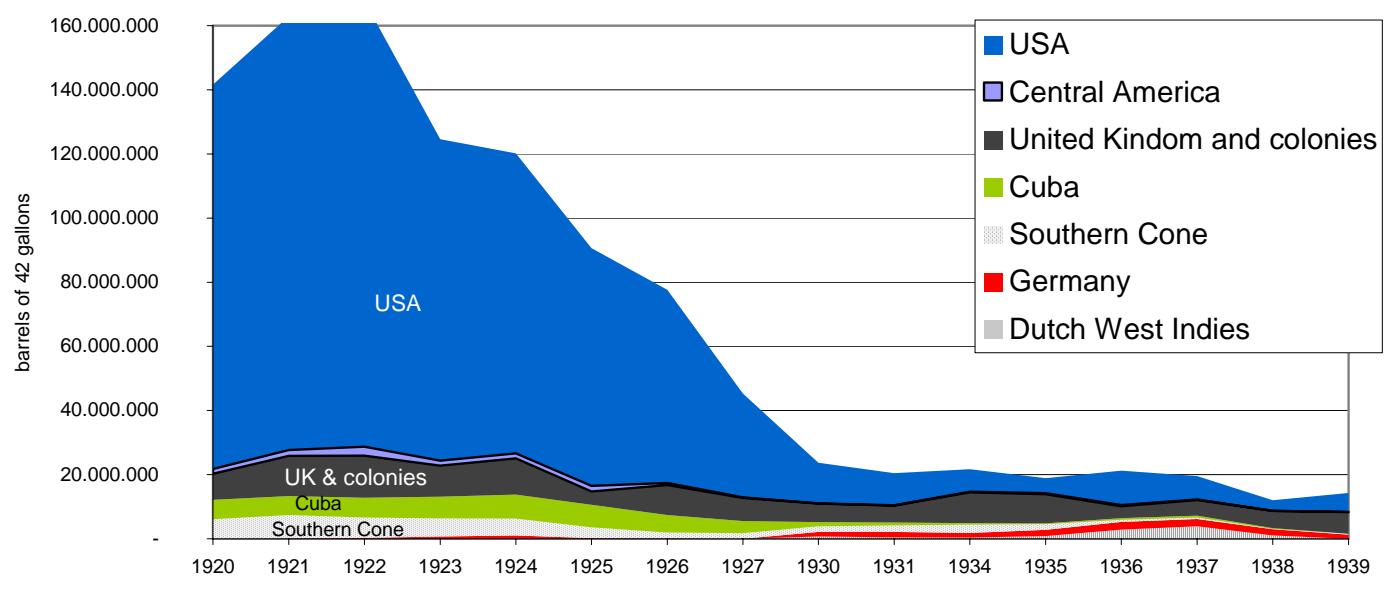

Source and notes: Mexico. Departamento de la estadística nacional. (various years). Central America includes Costa Rica, El Salvador, Honduras, Nicaragua and Panama. United Kingdom includes also the exports to British possessions such as Bahamas, Jamaica and British Honduras. Southern Cone refers to Argentina, Brazil, Chile and Uruguay.

Part of the perception of a sudden decline of the Mexican industry came from the fact that U.S. imports of Mexican oil did fall quite rapidly. By 1925 the U.S. imported from Mexico half the amount of crude oil imported in 1921; a fifth by 1927; twenty times less 
by $1933^{12}$. It can be observed that the rapid fall of the exports to the U.S. was not followed by an equal fall in exports to the other main destinations. Thus far the immediate assumption by the U.S. analyst was that Mexico was running out of oil at the same fast rate as the U.S. imports from Mexico declined. Yet the reasons for the decline of U.S. imports of Mexican oil relate more to the U.S. demand of foreign oil than to the supply of oil from Mexico.

The demand for imports of crude oil by the U.S., which peaked with the post-war shortage in 1921, halved by 1927. Furthermore, by 1933 the U.S. imported a fourth of the crude oil imported in 1921. The reasoning behind the reduction of crude imports into the U.S. was not that Mexico was unable to supply sufficient oil (Mexico produced enough oil to potentially fulfill the American demand until at least 1928) but the changes in the supply of oil within the U.S. and elsewhere that can be observed in Figures 4 and 7 above.

The fears of oil shortages of the early 1920s in the U.S. were replaced by an evergrowing surplus in the mid-1920s from the newly discovered fields in California, Arkansas, Texas, Oklahoma and, Louisiana, culminating in the huge main East Texas field in 1930. It is not mere chance that imports of oil into the U.S. declined as production gushed in California first (1923) and Oklahoma later on (1927). In fact, inventories of crude oil in the U.S. kept growing: 300 million barrels by the end of 1922, over 400 million by 1924, and more than 500 million barrels at the edge of the Great Depression. These levels multiply by many times the inventories levels shown in Figure 6 above. As a

\footnotetext{
${ }^{12}$ The U.S. imported 125 million barrels of crude oil from Mexico in 1921, 26 million in 1927 and only 5.8 million barrels in 1933. Data from the American Petroleum Institute (1937) p.208.
} 
consequence of the surplus petroleum within the U.S., prices maintained a declining trend for the rest of the decade as shown in Figure 8 above.

At the world level the surging production in Venezuela and Persia added to the return to production and exports of Russia (which began to be felt by 1924), plus the contribution of the new smaller producers of South America (Colombia, Peru, Ecuador and Trinidad). All together made that for the first time since the beginning of the War, supply of oil run ahead of demand from 1925 onwards.

The shortage ended, so it did the crucial role played by Mexican oil as supplier of the U.S. market. What did not end were the uncertainties in the world petroleum industry. The scenario for a worldwide rush for oil was set at the end of the War. Oil was sought out in more countries during the second half of 1920s than never before. Yet the nationalism awaken during the War made it difficult for the companies to secure new exploration contracts and nothing could guarantee that previously signed agreements were to be honored.

At the same time, the shortage confronted the U.S. petroleum industry with a largely overlooked problem. The oilmen and the government alike suddenly realized that the sources of supply of the domestic industry were concentrated within its own borders and in Mexico. It was the time to launch an 'aggressive American oil policy abroad', as labeled by DeNovo (1956). This new policy pushed U.S. companies to seek out new supplies on a worldwide basis, either by exploration or by purchase of existing production, just to find out things were not going to be that easy. It came as a bitter realization for U.S. oil companies to find that by the early 1920 s the British companies, which were currently turning out about 15 per cent of the world's production, had 
somehow acquired more than half the world's estimated future reserves thanks to the rights acquired by Royal Dutch-Shell and Anglo-Persian Oil Co which held quasimonopolies in Venezuela, Persia, Dutch East Indies, British East and West Indies.

It is not heroic to presume that the uncertainties in the world's petroleum industry had a negative impact on the Mexican oil industry. Not only had the U.S. lost interest in Mexican oil by mere fact of finding exceeding domestic supplies, but also the U.S. industry had now a new active policy for securing reserves elsewhere.

Haber et al. (2003) argued that the oil companies continued to explore and invest in Mexico well after output began to fall, and they simply left because they could not find more oil. The truth is that companies were exploring for oil in Mexico with less intensity that they were doing elsewhere during the 1920s as can be deducted from the figures of U.S. exports of petroleum machinery and equipment shown in Table 1.

Table 1

U.S. Exports of Oil Well Machinery to all countries and Mexico for selected years (real U.S. \$)

\begin{tabular}{|c|c|c|c|c|c|c|c|c|c|}
\hline \multirow[b]{2}{*}{ Year } & \multicolumn{3}{|c|}{ Total Oil Well Machinery } & \multicolumn{3}{|c|}{ 7341- Well Drilling aparatus } & \multicolumn{3}{|c|}{$\begin{array}{l}\text { 7349- Other Petroleum well and refining } \\
\text { machinery }\end{array}$} \\
\hline & $\begin{array}{l}\text { Exports to all } \\
\text { countries } \\
\text { real U.S. } \$\end{array}$ & $\begin{array}{c}\text { Exports to Mexico } \\
\text { real U.S. } \$\end{array}$ & $\begin{array}{c}\text { Mexican } \\
\text { share } \\
\%\end{array}$ & $\begin{array}{l}\text { Exports to all } \\
\text { countries } \\
\text { real U.S. \$ }\end{array}$ & $\begin{array}{l}\text { Exports to } \\
\text { Mexico } \\
\text { real U.S. \$ }\end{array}$ & $\begin{array}{c}\text { Mexican } \\
\text { share } \\
\%\end{array}$ & $\begin{array}{l}\text { Exports to all } \\
\text { countries } \\
\text { real U.S. } \$\end{array}$ & $\begin{array}{l}\text { Exports to } \\
\text { Mexico } \\
\text { real U.S. \$ }\end{array}$ & $\begin{array}{c}\text { Mexican } \\
\text { share } \\
\%\end{array}$ \\
\hline 1915 & $\$ 18.343 .175$ & $\$ 1.860 .437$ & 10,1 & & & & & & \\
\hline 1922 & $\$ 25.035 .840$ & $\$ 5.775 .994$ & 23,1 & $\$ 9.715 .077$ & $\$ 3.165 .586$ & 32,6 & $\$ 15.320 .763$ & $\$ 2.610 .408$ & 17,0 \\
\hline 1925 & $\$ 57.257 .369$ & $\$ 6.171 .324$ & 10,8 & $\$ 30.681 .972$ & $\$ 2.822 .112$ & 9,2 & $\$ 26.575 .397$ & $\$ 3.349 .212$ & 12,6 \\
\hline 1930 & $\$ 147.933 .354$ & $\$ 5.628 .565$ & 3,8 & $\$ 59.795 .404$ & $\$ 2.283 .509$ & 3,8 & $\$ 81.960 .093$ & $\$ 2.690 .702$ & 3,3 \\
\hline 1935 & $\$ 109.094 .297$ & $\$ 3.820 .920$ & 3,5 & $\$ 48.878 .319$ & $\$ 1.697 .710$ & 3,5 & $\$ 58.363 .638$ & $\$ 2.081 .768$ & 3,6 \\
\hline
\end{tabular}

Sources and notes: U.S. Department of Commerce (years 1915 to 1940). The CPI of the Bureau of Labour was used to convert nominal to real dollars. The total sum is not exact for 1930 and 1935 because a third entry (7350- Other well-drilling apparatus) that enters the statistic from 1929 has been disregarded here. It is a small entry of less than 4 percent in 1930 and 2 percent in 1935.

For sure the average flow of drilling investment into Mexico all along the 1920s, although declining, was higher than the drilling investments done in the previous decade. Yet, from the previous discussion it is also clear that the rush for oil speeded up all over the world after the War; so it did petroleum investment worldwide. Total exports of oil 
machinery and equipment from the U.S. more than doubled their value in real terms between 1922 and 1925, and by 1930 they were almost six times the value of 1922. As for drilling equipment, the crucial element for finding and extracting new reserves, the real value of U.S. exports trebled between 1922 and 1925, and doubled again the latter value by 1930. While Mexico received over a third of all drilling apparatus exported from the U.S. in 1922, it only got 9 per cent in 1925, and 3.8 per cent in 1930 . The flow of oil well drilling machinery into Mexico was clearly falling behind the growth of the oil industry worldwide.

An alternative hypothesis for the smaller flow of investment into Mexico can be that the sinking production justified smaller investments than elsewhere, or as argued by the geological explanation of Haber et al. (2003): the companies 'left Mexico when they could no longer find sources of petroleum that could be extracted at a reasonable price using existing technology' during the second half of the decade. However, the data just presented do not reveal that companies left Mexico in the second half of the 1920s, simply that they did not increase their investment as the same rate as elsewhere.

Investment continued into flow into Mexico at a relatively constant pace. Only at the time of the nationalization of the oil industry Mexico reached the minimum investment flow of the whole period studied. The companies only left when their property was expropriated in 1938.

Of course the blow out of Venezuela's oil fields by 1922 drove immense amounts of oil drilling equipment to that country. Yet, by 1924 both the British East Indies and Mexico were still receiving more drilling machinery of U.S. production than Venezuela according to the same data of the U.S. Department of Commerce (years 1915 to 1940). A year 
after, however, not only Venezuela has surpassed the level of new investments of Mexico, but also the British East Indies, the Dutch East Indies and even Argentina were receiving drilling machinery for greater value than Mexico. At the end of the decade the list of countries receiving more oil drilling machinery than Mexico also included the Soviet Union, Canada, Rumania, the British West Indies and Colombia, with Persia getting real close to the Mexican levels. Nevertheless, of the long list of countries receiving greater amounts than Mexico of drilling equipment only two countries, Venezuela and the Soviet Union, produced more oil than Mexico by 1929. From this discussion, it is clear than Mexico was losing out in new investment compared to the rates of new investments elsewhere in the industry.

The question of whether Mexico was running out of oil that could be extracted with the existent technology remains to be explored in this context. There are few estimates of proven reserves in the $1920 \mathrm{~s}$, but the few available can be used to show that Mexican proven reserves were not behind those of the other oil producers of the time. White (1920) of the Foreign Mineral Section of the U. S. Geological Survey estimated the world's reserves of main petroleum countries in 1920. He estimated Mexican oil reserves were 4525 million barrels, while Venezuela's were estimated at 105 million barrels in the same year. Even if no additional oil was found in Mexico along the following 20 years (which is not true) and subtracting the actual Mexican cumulative production, Mexican reserves in 1925 can be calculated approximately at 3500 million while Venezuelan were said to be 500 million barrels. Still by 1935 Mexico's fields would hold further 3100 million barrels while Venezuela's proven reserves were estimated at 2900 million $^{13}$.

\footnotetext{
${ }^{13}$ Venezuelan reserves for years 1925 and 1935 from: United Nations. Economic Commission for Latin America (1960), p.59. For years 1919, 1924, 1929, 1934 and 1939: Martínez (1989), p.166.
} 
Thus, at least in the 1920s Mexico's future as oil producer looked as bright as its main competitor, Venezuela.

It could also be argued that petroleum seek and found elsewhere was cheaper and of higher quality than Mexican oil, thus with greater competence Mexican oil industry was unable to survive. By the mid 1920s he U.S. started to import oil from countries different than Mexico (Venezuela, Colombia, Peru, Ecuador and Trinidad). The immediate question is whether these countries had any cost or quality advantage over Mexico. Table 2 report the results of an enquiry by the U.S. Tariff Commission (1932) in this direction. The results indicate that in fact, only Venezuelan oil was cheaper to import into the U.S. than Mexican oil, but none of the other countries had any price advantage over Mexico. The report does not suggest that neither of the competing countries had any quality advantage over Mexico.

Table 2

Quantities of foreign crude oil used by U.S. Atlantic coast refineries and average delivered price per barrel (1927-1930)

\begin{tabular}{|c|c|c|c|c|c|c|c|c|c|c|c|c|}
\hline \multirow[b]{2}{*}{ Year } & \multicolumn{2}{|c|}{ Venezuela } & \multicolumn{2}{|c|}{ Mexico } & \multicolumn{2}{|c|}{ Colombia } & \multicolumn{2}{|c|}{ Peru } & \multicolumn{2}{|c|}{ Trinidad } & \multicolumn{2}{|c|}{ Ecuador } \\
\hline & mill. Barrels & $\$$ per barrel & mill. Barrels & \$ per barrel & mill. Barrels & $\$$ per barrel & mill. Barrels & \$ per barrel & mill. Barrels & $\$$ per barrel & mill. Barrels & $\$$ per barrel \\
\hline 1927 & 12,2 & $\$ 1,49$ & 10,5 & $\$ 1,69$ & 8,5 & $\$ 2,05$ & 1,4 & $\$ 2,23$ & 0,2 & $\$ 1,35$ & 0,1 & $\$ 1,74$ \\
\hline 1928 & 39,3 & $\$ 1,04$ & 9,4 & $\$ 1,31$ & 12,1 & $\$ 1,65$ & 1,5 & $\$ 2,05$ & 0,3 & $\$ 1,44$ & 0,2 & $\$ 1,23$ \\
\hline 1929 & 36,2 & $\$ 1,07$ & 4,3 & $\$ 1,20$ & 12,3 & $\$ 1,76$ & 1,9 & $\$ 2,48$ & 0,3 & $\$ 1,23$ & 1,2 & $\$ 1,31$ \\
\hline 1930 & 33,2 & $\$ 1,07$ & 5,6 & $\$ 1,14$ & 14,33 & $\$ 1,71$ & 1,2 & $\$ 2,27$ & 1,1 & $\$ 1,18$ & 1,1 & $\$ 1,29$ \\
\hline
\end{tabular}

Source: U.S. Tariff Commission, Production Costs of Crude Petroleum and of Refined Petroleum Products (1932), p.180, table 97

From the account in this section it seems that there are enough channels through with the events in the industry at the international level affected the decline of the Mexican industry. The end of the shortage and the changes and uncertainties in the petroleum industry worldwide help to understand better the sudden decline of the Mexican industry, beyond the domestic incidents signalled in the first section of the paper. 


\section{CONCLUSIONS}

Thanks to the data of the American Petroleum Institute, the U.S. Department of Commerce, and the Mexican Government this paper has placed the early Mexican oil industry within the changing context of the world oil markets of the early 1920s. This brings the international perspective into an historiography that to date had remained mostly concentrated on events within Mexico and which paid far more attention to the decline of the industry than to the reasons for the abrupt rise during the years of the First World War.

However intense were the domestic challenges, stepping out of Mexico allows to show these were related to the extensive changes taking place in the petroleum industry worldwide during the First World War and its aftermath, including the surge in demand and the awaken of nationalism world-wide regarding the exploitation of petroleum resources. The intense growth of demand for petroleum products in the world was not followed by an equal growth in supply. The distortions introduced by the War, the Soviet Revolution, the cold winters of the end of the 1910s, plus the final War effort produced the first petroleum shortage of the $20^{\text {th }}$ century between the years 1918 and 1921 . The importance of Mexican oil at this time of shortage should not be underestimated for it was crucial for the U.S. markets, and by re-export to the European markets. Indeed, the shortage was at the root of the Mexican sudden rise of petroleum output between 1918 and 1921. The shortage ended, what did not end were the uncertainties in the petroleum industry worldwide. The former terminated with the need of Mexican oil by the U.S. refineries, the latter contributed to relegate the Mexican oil industry to a secondary role 
when the new active policy for securing reserves elsewhere implied losing out in new investment.

Overall, the paper shows that the changes that took place in the petroleum industry worldwide during the Great War years and its aftermath, and the shortage of oil that occurred in the world's markets between 1918-1921 are crucial events in order to understand the early rise of the Mexican oil industry and set the basis for a better understanding of the subsequent sudden decline.

\section{REFERENCES:}

\section{Sources}

American Petroleum Institute. (1937): Petroleum Facts and Figures. New York.

COLEGIO DE MÉXICO. (1960): Estadísticas económicas del Porfiriato: comercio exterior de México, 1877-1911. México D.F.

COlegio de MÉXICO, SEMINARIO de Historia Moderna de MÉXICO. (1965): Estadísticas económicas del Porfiriato: fuerza de trabajo y actividad económica por sectores. México D.F.

DARMSTADTER, J. and E. AL. (1971): Energy in the World Economy, A Statistical Review of Trends in Output, Trade and Consumption since 1925. London.

LLOYD's REGISTER OF SHIPPING. (s.d.): "World's fleet statistics."

MÉXICO, Government OF. (1925): "Estadísticas del Petróleo." Estadística Nacional., Febrero:4, pp. 26.

MÉXICO, Government Of. (1937 December): "Estadística Petrolera." Revista de Industria. Revista Mensual, 1:2, pp. 21.

MeXico. DePARTAMENTO DE LA ESTADíSTICA NACIONAL. (various years): Anuario estadístico, comercio exterior y navegación.

MÉXICO. INSTITUTO NACIONAL DE ESTADÍSTICA GEOGRAFÍA E INFORMÁTICA (INEGI). (1994): Estadísticas históricas de México. México D.F.

MÉXICO. SeCRETARÍA DE HaCIENDA Y CRÉdito PÚBliCo. DePARTAMENTO DE IMPUESTOS ESPECIALES. SECCIÓN DE PETRÓLEO. (1936a): Cuadros estadísticos del petróleo, 19251930. México D.F.

MÉXICO. SECRETARÍA DE HACIENDA Y CRÉDITO PÚBLICO. DEPARTAMENTO DE IMPUESTOS ESPECIALES. SECCIÓN DE PETRÓLEO. (1936b): Cuadros estadísticos del petróleo, 1930-1935. México D.F.

MÉXICO. SECRETARÍA DE HACIENDA Y CRÉDito PÚBliCo. DiRECCIÓN GENERAL TÉCNICA DE INGRESOS. OFICINA DE INVESTIGACIONES ECONÓMICAS. (1938): La Industria del Petróleo en México. México, D.F. 
MéXico. Secretaría de Patrimonio Nacional. (1963): El Petróleo de México. México D.F.: Goverment.

NBER. (2003): "Crude petroleum stocks, end of month. NBER SERIES: 05013." Macrohistory database: http://www.nber.org/databases/macrohistory/contents/chapter05.html.

PEMEX, (Petróleos MeXiCANos). (1952): Informes del Director General Senador Antonio J.Bermúdez 1947-1952. México D.F.

PeMeX, (Petróleos Mexicanos) ed. (1988): La Industria Petrolera en México : una Crónica. México D.F.

U.S. DePARTMENT OF COMMERCE. (various years): Commerce Year Book. Washington D.C.: Government Printing Office.

U.S. DEPARTMENT OF COMMERCE. (years 1915 to 1940): Foreign Commerce and Navigation of the United States. Washington D.C.: Government Printing Office.

U.S. DePARTMENT OF COMMERCE (By J.R. BRAdLEY). (1931): Fuel and Power in Latin America. Washington D.C.: Government Printing Office.

U.S. DePARTMENT OF COMMERCE (BY W.A. OtTIS). (1924): "The Petroleum Industry of Russia." Trade Information Bulletin. Supplement to Commerce Reports,No.263.

U.S. FEDERAL TRADE COMMISSION. (1923): Foreign Ownership in the Petroleum Industry. Washington D.C.: Government Printing Office.

U.S. TARIFF COMMISSION. (1932): Production cost of petroleum products and of refined petroleum products. Washington, D.C.: Government Printing Office.

UNITED NATIONS. ECONOMIC COMMISSION FOR LATIN AMERICA. (1960): "Economic Developments in Venezuela in the 1950s." Economic Bulletin for Latin America, 1:1, pp. 21-61.

\section{Other references}

AdLESON, S. L. (1992): "The Cultural Roots of the Oil Workers' Unions in Tampico19101925'," in The Mexican Petroleum Industry in the Twentieth Century. J.C. Brown and A. Knight eds. Austin: University of Texas Press.

BALDRIDGE, D. C. (1987): Mexican Petroleum and the United States-Mexican relations, 19191923. London.

Bermudez, A. J. (1963): The Mexican National Petroleum Industry: A case study in Nationalisation. Stanford.

Brown, J. C. (1985): "Why Foreign Oil Companies Shifted Production from Mexico to Venezuela during the 1920s." American Historical Review (American Historical Review),:90, pp. 362-85.

Brown, J. C. (1993): Oil and Revolution in Mexico. Oxford: University of California Press.

CÁRDENAS, E. (COMPILADOR),. (1992-1994): Historia Económica de México (5 Vols). México, D.F.

DeNovo, J. A. (1956): "The Movement for an Aggressive American Oil Policy Abroad, 19181920." The American Historical Review, 61:4, pp. 854-76.

Grayson, G. (1980 ): The Politics of Mexican Oil. Pittsburgh.

HABER, S., N. MAUER, and A. RAZO. (2003): "When Law Does Not Matter: The Rise and Decline of the Mexican Oil Industry." Journal of Economic History, 63:1, pp. 1-32. 
HABER, S. H. (1989): Industry and Underdevelopment. The Industrialisation of Mexico, 18901940. Stanford.

HABER, S. H., N. MAUER, and A. RAZO. (no published): "When Institutions do not Matter: The Rise and Decline of the Mexican Oil Industry." Paper presented at the Economic History Seminar at UC Berkeley, September 2001.

KNIGHT, A. (1992): "The Political Economy of Revolutionary Mexico, 1900-1940," in Latin America, Economic Imperialism and the State: The Political Economy of The External Connection form Independence to the Present. C Abel and C.M. Lewis eds. London, pp. 288-366.

LÓPez PORTILlo, J. (1938): "Las Reservas Petroleras Mexicanas." Revista de Economía (Revista de Economía), II:7-12, pp. 475-85.

LÓPEZ PORTILlO, J. (1975): El petróleo de México. México D.F.

Manterola, M. (1937): "La Situación de la Industria del Petróleo en México y su Reciente Nacionalización." Revista de Economía (Revista de Economía), I:1-6, pp. 361-77.

MARTíNEZ, A. R. (1989): "El papel de la explotación petrolera en el proceso de modernización de la sociedad venezolana y la perspectiva inmediata," in Hacia la Venezuela Postpetrolera [conference sponsored by la Academia Nacional de las Ciencias Económicas in 1985]. Francisco Mieres ed. Caracas: Academia Nacional de Economía, pp. 151-77.

MENÉnDEZ, G. A. (1958): Doheny, el cruel. México D.F.

Novelo, V. (1991): La difícil democracia de los petroleros. México, D.F.

OWEN, E. W. (1975): Trek of the Oil Finders : A History of Exploration for Petroleum. Oklahoma.

PHILIP, G. (1982): Oil And Politics In Latin America. Nationalist Movements And State Companies. Cambridge.

RAMirez Heredia, R. (1979): La otra cara del petróleo. México, D.F.

REYNOLDS, C. W. (1970): The Mexican Economy. Twentieth-Century Structure and Growth. London.

RIPPY, M. (1972): Oil and The Mexican Revolution. Leiden.

SANGines Villavalva, E. (1938 Marzo): "La industria petrolera en México." Revista de Hacienda (Revista de Hacienda), II.

Silva HerzoG, J. (1938): "La expropiación de las compañías petroleras en México." Revista de Economía (Revista de Economía), II:7-12, pp. 447-57.

THORP, R. (1989): "Economy, 1914-1929," in Latin America Economy and Society 1870-1930. L Bethell ed. Cambridge, pp. 57-82.

ThORP, R. (1998): Progress, Poverty and Exclusion. An Economic History of Latin America in the 20th Century. New York: Inter-American Development Bank.

White, D. (1920): "The Petroleum Resources of the World." Annals of the American Academy.

WiLkIE, J. W. (1967): The Mexican Revolution: Federal Expenditure and Social Change since 1910. Berkeley: University of California press.

WILKINS, M. (1974): "Multinational Oil Companies in South America in the 1920s: Argentina, Bolivia, Brazil, Chile, Colombia, Ecuador and Peru." Business History Review, 48:3, pp. 414-46.

YERGUIN, D. (1991): The price: the epic quest for oil, money and power. New York: Simon\&schuster. 